\title{
Economic Valuation of River Restoration: An Analysis of the Valuation Literature and its Uses in Decision-Making
}

\begin{abstract}
This paper provides an analysis of existing non-market valuations of river restoration primarily in the United States and Europe. The goals of the river restoration in terms of ecosystem services are identified, as are the valuation methods used. More than two-thirds of the 38 river restorations reviewed sought to restore and protect fish populations, including in many cases threatened or endangered species. River restorations were also frequently undertaken to improve wildlife habitat, and water quality for boating. In terms of the use of non-market valuations in decision making, six of 38 restorations reviewed involved benefit-cost analyses or environmental assessments or equivalent decision documents. While both revealed preference and stated preference methods were used for valuing river restorations, the majority of restoration valuations ( 27 out of 38 , about $70 \%$ ) utilized stated preference methods such as the contingent valuation method (CVM) and choice experiments (CE). Annual willingness-to-pay per household estimated from the stated preference methods appear logically and positively related to the miles of river restored demonstrating weak scope.
\end{abstract}

Keywords: river restoration, ecosystem goods and services, economic valuation, revealed preference, stated preference, decision-making.

Acknowledgements. Support for this research was provided by the U.S. Department of Agriculture Regional Research Project W-3133 (Benefits and Costs of Natural Resources Policies Affecting Ecosystem Services on Public and Private Lands) through the Colorado State University and University of Georgia Agricultural Experiment Stations. 


\section{Introduction}

The earth's 33,000 rivers (Vorosmarty et al. 2000) play a major role in shaping not only the physical landscape of the planet but have a pervasive influence on the well-being of people around the world. The United States alone has 3.5 million miles of rivers and streams in the US (US EPAa 2015). Rivers worldwide provide many ecosystem goods and services. These include provision of drinking water as well as supporting fish and wildlife people enjoy for fishing, hunting, viewing, and just knowing they exist. Water based recreation such as boating and swimming is also a significant use of rivers. Free flowing rivers and streams can enhance property values of those living along them (Lewis et al. 2008; Provencher et al. 2008). Natural processes in rivers and streams help dilute wastewater discharges to maintain water quality which enhances other ecosystem goods and services. Besides these on-site and downstream use values, rivers and streams provide habitat for threatened and endangered species for which the public has significant non-use or passive use values (Richardson and Loomis 2009).

However, the ability of rivers and streams (hereafter referred to simply as rivers), is compromised by many pollutants, most notably excessive nutrients (e.g., phosphorous and nitrogen) that lead to algae blooms and low oxygen levels. These conditions reduce a river's ability to support game fish, and fish dependent wildlife. Nearly $10 \%$ of rivers in the US have bacteria making the water unsafe for human consumption and water contact recreation (US EPAa 2015). Mercury continues to be a problem in thousands of miles of rivers as it concentrates in fish so much that people are advised not to eat them. In many cases, river-daming also poses a threat to the survival of many native species due to the reduction of fish passage for migratory fish and alternations in water temperatures and river flow regimes. 
Restoring rivers so they can provide their potential ecosystem goods and services is expensive. Bernhardt et al. (2005) tabulated total costs of river restoration since 1990 in the US at \$14-15 billion. As these authors note, this total does not even include millions of dollars of expenditures on some large river restoration projects such as the Kissimmee River in Florida, the Colorado River through Glen Canyon/Grand Canyon in Arizona, the Columbia River in the Pacific Northwest region of the US and the Missouri River in the Midwest region of the US. Given that the US EPA estimates that slightly more than half the rivers in the U.S. are in poor biological condition (e.g., unable to support many forms of native aquatic life), even $\$ 15$ billion falls short of restoring the levels of ecosystem goods and services that could potentially be provided by US rivers (US EPAa 2015).

River restoration issues and problems are not limited to the US, as the European Union (EU) also has dammed thousands of miles of rivers (Kristensen and Hansen 1994). A significant proportion of the EU's rivers are affected by organic pollutants and nutrients from cities and industries. According to Kristensen and Hansen (1994: 11) "Eutrophication is a widespread problem in Europe." In particular, nitrate levels have increased in more than two thirds of Europe's 230 rivers (Kristensen and Hansen 1994:12). These authors also note that successful restoration is an expensive and a lengthy process. Thus there is a need for valuation information to justify expensive restoration effects, particularly in Europe's stagnating economy. ${ }^{1}$

\footnotetext{
${ }^{1}$ Australia also has engaged in substantial river restoration efforts. In particular, The Australian government has been spending more than $\$ 100$ (AUD) annually on river restoration projects throughout the country (National Water Commission, 2009).
} 
The primary purpose of this paper is to summarize what is known about valuation of river restoration in states throughout the US, Europe and other countries. We cast this discussion in terms of ecosystem goods and services. Even though some of the older studies pre-dated development of the ecosystem goods and services framework (e.g., see Brown et al. 2007), we were able to also recast these older studies in this framework. We begin by discussing policies and programs that authorize, guide and fund river restoration. Next, we describe our classification system developed to assess what ecosystem goods and services have been studied as part of various types of river restoration projects (e.g., fisheries, threatened and endangered species, outdoor recreation). We apply this classification system to studies which valued river restoration in various states in the U.S. and other countries primarily in Europe, and report results of the valuation methods used. The paper concludes with a discussion how these river restoration values have been used in the decision making process.

\section{U.S. and European River Restoration Policies and Programs}

River restoration in the US is governed by a number of federal policies and programs in cooperation with state and local government agencies. The US Clean Water Act provides overarching legislative authority and funding for river restoration in the states. Section 404 of the Clean Water Act establishes a permit program that regulates the discharge of dredged and fill material into waters of the US including rivers and riparian wetlands. The US Army Corps of Engineers is the designated federal agency in charge of the Section 404 permitting process. This permitting process would likely be a component of any river restoration plan, program or project in the US, and could be used to prevent water quality degradation through discharge of dredged and fill material into river waters and associated riparian wetlands. 
Section 303 of the Clean Water Act requires US states, territories, and Native American tribes to identify and list impaired waters within their jurisdictions which fail to meet federal water quality standards. These waters are then subject to protection or restoration in order to meet "total maximum daily loads" (TDML) of water pollutants. A TMDL specifies the maximum amount of a pollutant that can occur in a water body on a daily basis. For example, restoring riparian wetlands along an impaired river may help meet the TMDLs for that river (US EPAb). Section 319 of the Clean Water Act provides for funding of specific river restoration projects such as those conducted through the San Francisco Bay Water Quality Improvement Fund administered by the US Environmental Protection Agency (US EPAc).

Another major federal policy affecting river restoration in the US is the Comprehensive Environmental Response, Compensation, and Liability Act of 1980 (CERCLA). Along with provisions in the Clean Water Act and Oil Pollution Act of 1990, CERCLA empowers public natural resource "trustees" to recover monetary compensation for damages caused to natural resources in the US including river and riparian wetland ecosystems. Under the authority of these federal policies, the US Department of the Interior has established what is termed "The Natural Resource Damage Assessment and Restoration Program". With the Interior Department along with other federal, state and Native American tribal partners acting as trustees for fish and wildlife resources, the objectives of this program are to assesses human-induced damages to public natural resources, recover monetary compensation for the damages, and then use the monies recovered to help restore the damaged ecosystems. Restoration projects include river and 
riparian wetlands restoration projects administered by the U.S. Fish and Wildlife Service (US FWS) - a division of the U.S. Department of the Interior (US FWS 2015).

At the federal level, the US Natural Resources Conservation Service (US NRCS) also receives funds for river restoration projects under the conservation and environmental quality titles in the omnibus US Farm Bill. These projects tend to be more small-scale and local in nature, for example, providing technical assistance to riparian landowners in a small watershed to stabilize river banks and corridors using plants and plant materials for slope protection, erosion control, and natural buffers. Such projects often utilize multiple public and private partnerships and funding sources (US NRCS 2015).

Identifying polluted rivers and developing plans for restoring and protecting these rivers under Section 303 of the Clean Water Act in the U.S. is similar to the purpose and objectives of river restoration in the EU under the European Water Framework Directive established in the year 2000 by the European Commission (EC). This policy commits all EU member states to achieve "good" ecological and chemical status in EU waters by the target year of 2015. Restoration of heavily modified water bodies is considered in the Directive as an important means to achieve good ecological status (e.g., see Vermaat et al. 2016).

In addition to setting common water quality goals across the EU, the Directive established river basin planning districts based on natural watershed boundaries, rather than political boundaries. This new river basin legislative and management approach is designed to facilitate cooperation and collaboration between EU member states in restoring and protecting rivers and other water 
bodies that cross state boundaries (ECa 2015). Assessments of the Directive's effectiveness are underway as this article is being written. The most recent European Commission report on the implementation of the Directive suggests that progress has been slow in achieving the goal of all EU waters reaching a "good" status (ECb 2015).

\section{Ecosystem Goods and Services Potentially Provided by Restored Rivers}

Using the classification system of Brown et al. (2007) as guidance, we developed a check-list of ecosystem goods and services likely provided by rivers and river restoration projects. Following other authors (e.g., Boyd and Banzaf 2005), we define and classify ecosystem goods and services from an anthropocentric perspective as things that are of direct value to people. This anthropocentric perspective draws an important distinction between ecosystem goods and services, and ecosystem processes or functions.

Ecosystem processes and functions include the complex chemical cycles (e.g., carbon, nutrient and hydrological cycles) and biological actions and operations (e.g., food web, life cycles) that are ultimately powered by the one-way flow of solar energy from the sun. From an economic (and anthropocentric perspective), people do not gain utility or satisfaction directly from ecosystem processes or functions. Rather, ecosystem processes and functions naturally "produce" or generate outputs (ecosystem goods and services) that, in turn, directly or indirectly provide utility or satisfaction to people (Brown et al. 2007).

Similar to Daily (1997), Brown et al. (2007) also draw a distinction between ecosystem goods and ecosystem services. Brown et al. (2007) define ecosystem goods generally as tangible, 
material products resulting from ecosystem processes or functions. Ecosystem goods arising from ecosystem processes and functions associated with river restoration include: threatened and endangered species (T\&E), native fish, wildlife, and recreational resource. Measures of ecosystem goods associated with river restoration include the size of native fish populations and miles of river with public access for recreational walking and fishing.

Ecosystem services are generally defined as improvements in the condition or location of things of value to people (Brown et al. 2007). For example, ecosystem processes and functions associated with river restoration are expected to improve water quality. For human valuation purposes, water quality can be disaggregated into boatable, fishable, swimmable, and drinkable following the commonly used Resources for the Future water quality ladder (Mitchell and Carson 1989). Measures of ecosystem services associated with river restoration include units of a river (e.g., surface acres, gallons) suitable from a water quality perspective for swimming, fishing, boating and/or human consumption.

The economic values of ecosystem goods and services include use values and non-use or passive use values. Use values include direct use of river resources such as on-site recreation, off-site consumption of fish caught in a river, and drinking water withdrawn from a river. Non-use or passive use values include the utility or satisfaction people derive from just knowing that certain fish and wildlife species (e.g., T\&E species) continue to exist in rivers (existence value). 


\section{Data Collection and Results}

\subsection{Literature Search}

Our literature searching strategy began with a list of known river restoration studies such as the Elwha Dam removal and the Glen Canyon/Grand Canyon. This was supplemented by a comprehensive electronic search of the gray and published literature. Following our definition and classification of ecosystem goods and services discussed above, for this electronic search we used the following key words: river restoration, evaluation, economic values, ecosystem goods and services. Electronic search engines employed included EconLit, Google Scholar and ScienceDirect.

The references found in the known sources and additional sources identified in the electronic search served as additional items to be reviewed. After carefully examining and crossreferencing the results of the three electronic search engine results and the references cited in all of the uncovered papers, we felt confident that our literature search was comprehensive of almost all river restoration valuation studies conducted to date, particularly in the US and Europe. ${ }^{2}$ Since the focus of this paper is to review those studies involving economic valuation of river restoration, we do not review the many river restoration efforts that did not estimate economic values of ecosystem goods and services. Bernhardt et al. (2005) provide a summary of river restoration projects in the U.S. including those involving little or no economic valuation. We also do not review the many studies that did not focus specifically on valuing river restoration,

\footnotetext{
${ }^{2}$ We say comprehensive of almost all studies because the possibility always exists we missed studies that for some reason are not well-documented in electronic data bases or well-cited in previous studies. This may particularly be the case for studies conducted outside of the US and Europe where publication practices may not be distributed as widely (e.g., developing countries).
} 
such as the numerous valuation studies of river health in Australia reviewed by Rolfe and Brouwer (2012). ${ }^{3}$

\subsection{Ecosystem Service Goals of River Restoration}

Our literature review identified a total of 32 studies of river restoration. Our database is composed of 24 U.S. river restoration studies, six in Europe, one in Mexico and one in China, where one or more ecosystem goods or services were quantified and valued. Four of the 32 studies involved two different river restoration valuation efforts, and one involved three (Brouwer et al. 2016), which brought the total number of river restoration valuation efforts reviewed up to 38 . Table 1 summarizes these studies. These studies are geographically-broad with a wide range of river stretch lengths valued.

\section{[Table 1 about here]}

As evident from Table 1, the most prevalent goal of the reviewed river restoration valuations was restoration of fisheries (about $68 \%$ of restorations). Threatened and endangered fish was the focus of about one-quarter of the restoration valuations. Other fisheries oriented river restorations focused on the restoration of native fish. Restoring or improving recreational sport fishing was also a frequent goal of fisheries oriented river restorations. Dam removal primarily for the benefit of migratory fish was the purpose of about $21 \%$ of the restorations.

\footnotetext{
${ }^{3}$ In the Van Bueren and Bennett (2004) study in Australia, "restoration of river kilometers" was included as one attribute of a broader environmental protection policy that also included, for example, farmland protection. However, unlike the other studies we reviewed, they did not specify a specific river or river segment that was valued - only generic "rivers kilometers" in a large region.
} 


\subsection{Scale of River Restorations}

The scale of the river restoration varies enormously. The largest river restoration effort was the Missouri River at 1,700 miles (2,720 km) from Montana to Kansas City, Missouri. Most of the rest of the river restorations average 80 miles $(128 \mathrm{~km})$ of restoration, with the smallest in the range of $0.25-24$ miles $(0.40-38 \mathrm{~km})$, while several others were in the range of 40-170 miles (64$272 \mathrm{~km}$ ). The scale of the river restoration poses a bit of a conundrum for valuation efforts. Too small a size may not be worth expending the budgetary resources to perform a site specific original valuation. However, too large a project can make it difficult to conduct a well-focused valuation study of more than 1-2 ecosystem goods and services, even if budget resources allow such a study. For example, the valuation studies of the Klamath River restoration of 120 river miles (192 km), the Elwha River restoration of 70 river miles $(112 \mathrm{~km})$, and the Snake River dam removal valuation study of 140 river miles $(224 \mathrm{~km})$ largely focused on salmon recovery. Only the Welsh et al. (1997) study of the 300 river mile $(480 \mathrm{~km})$ stretch of the Colorado River through Glen and Grand Canyons valued several natural resources as a group (endangered fish, game fish, beaches, tribal cultural resources, and birds).

\subsection{Economic Value Estimates for River Restoration}

Willingness-to-pay (WTP) is a standard metric for measuring the economic value to people of both market and non-market goods and services (Brown et al. 2007). Estimates of annual WTP per household for river restoration from CVM studies, and CE studies that provided theoretically consistent estimates of total welfare changes (e.g., see Roe et al. 1996), are presented in Table 2. The CVM and CE welfare change (WTP) estimates in Table 2 provide a value per household for a bundle of river restoration attributes, for example, miles of river restored, provision of 
swimmable and drinkable water, and recovery of native fish and wildlife populations. The CE studies also provide estimates of the marginal value (or implicit price) of river restoration attributes which are shown in Table A1.

\section{[Table 2 about here]}

In Table 2, WTP generally rises with more miles of river restored and number of ecosystem goods and services valued illustrating a form of weak scope. ${ }^{4}$ For example, the second highest WTP per household is for the Welsh et al. (1997) study that valued the most river miles restored, and one of the highest numbers of ecosystem goods and services valued. Mansfield et al. (2012) and Loomis (1996) not only focused on river restoration for an iconic migratory fish species in the Pacific Northwest (salmon), but also involved dam removal and hence restoration of a free flowing river.

Even though we can only draw 16 observations from Table 2 to perform a regression analysis, we experimented with estimating a very simple WTP function in order to quantitatively test scope. ${ }^{5}$ The estimated WTP function includes four explanatory variables: miles of river restoration valued, number of ecosystem goods and services valued, valuation method, and country where the valuation study took place. For the regression, the number of ecosystem goods and services valued was split into two groups with $0=$ two or less and $1=$ greater than two. The valuation method was also an indicator variable with $0=$ continent valuation method and 1=choice experiment. Additionally, the country where the study took place was an indicator

\footnotetext{
4 "Weak scope" generally means that economic value (e.g., WTP) increases with the quantity and/or quality of a good or service provided. For a discussion of the meaning and significance of "scope" as an indicator of the validity of stated preference valuation techniques including CVM and CE, see Giraud et al. (1999) and Lew and Wallmo (2011).

${ }^{5}$ We were not able to use the Ojeda et al. (2007) and Zhongmin et al. (2003) WTP estimates in the regression because these studies did not specify the number of miles of river restored.
} 
variable with $0=$ U.S.A. and $1=$ other (non-U.S.A.). The regression equation, with annual WTP per household as the dependent variable, was estimated using ordinary least squares.

The results of the regression analysis are shown in Table 3. The estimated coefficient for miles of river restoration valued was positive and statistically significant at the .05 level. This result provides quantitative support for weak scope, that is, WTP increases with river miles restored. In particular, the estimated coefficient suggests that WTP increases by about $\$ 0.50$ per additional river mile restored, ceteris paribus.

The estimated coefficient for number of ecosystem goods services valued was also positive, suggesting that weak scope also holds for this variable. The estimated coefficient for the valuation method was positive suggesting choice experiments generated ceteris paribus higher WTP values as compared to the contingent valuation method. This result is consistent with previous studies (e.g., see Hanley et al. 1998; Richardson and Loomis 2009). The estimated coefficient for the country variable was negative suggesting WTP values were lower for studies conducted outside of the U.S.A. However, since the coefficient estimate for all three of these variables were not statistically significant, we cannot draw firm inferences about the effects of the number of ecosystem goods and services valued, valuation method, and country where the valuation study took place. All of the regression results reported in Table 3 and discussed above should be viewed as very preliminary due to the small number of observations (which also contributes to the low R-Squared value for the model).

[Table 3 about here] 
The eleven choice experiment studies we reviewed provide marginal values for many differently defined, and in most cases, not directly comparable river restoration attributes. However, there were a few common types of attributes in the seven otherwise distinct studies. Three of the seven studies had a measure of the quantity of riverine habitat (two as miles open for migratory fish, one as simply miles of wetted streams). Four different studies had some measure of the number of migratory fish (two of the studies focused on salmon, two on migratory fish generally). However, even in this case the attribute is not defined in the same units (e.g., one uses number of fish, one the percentage increase in an unknown population, and two use percent changes in probability of survival). Consequently, the resulting marginal values are not comparable in any meaningful way. Thus, in Table A1 we simply display the specific attributes and marginal valuations (implicit prices) for each CE study, but we do not attempt to summarize the marginal values as we did for the annual WTP values in Table 2 because of the high variability in how attributes were defined and measured.

\subsection{Use of Economic Values in River Restoration Decision-Making}

The details of the particular valuation methods and how the resulting valuations were used in the decision making process are presented in Table 4. As indicated in Table 4, there has been a great deal of original empirical studies conducted to value river restoration. Stated preference methods were the most common with the contingent valuation method (CVM) used in 13 of the 38 river restoration valuations (34\%), and choice experiments (CE) used in 14 of the 38 valuations (37\%). Two valuations used the hedonic price method (HPM), two used the travel cost method (TCM), and three used benefit transfer (BT). Two valuations used simulation models (SIM) to value carbon storage (Bagstad et al. 2013; Patton et al. 2015) and two used the replacement cost 
approach (RC) to value restored stream bank vegetation (shading) for lowering river water temperatures (Dubgaard et al. 2005; Honey-Rosés et al. 2013).

It should be noted that a limitation of using revealed preference methods including TCM and HPM is that these methods do not capture non-use values. This same limitation applies to simulation models (SIM) used to measure carbon storage and the replacement cost approach (RC). Omission of non-use values, if they are present, may lead to incorrect policy and management decisions, based for example on benefit-cost analysis, by undervaluing river restoration benefits.

\section{[Table 4 about here]}

In terms of the use of valuation results in river restoration decision making, we adopted the classification scheme of Laurans et al. (2013). These authors identify three potential roles of valuation information in actual decision making: (1) Decisive; (2) Technical; and (3) Informative. By "Decisive", Laurans et al. (2013) mean that the valuation exercise was seen as contributing significantly to a decision-making process for a specific project or policy. Their definition of "Technical" is rather narrow and applies to the application of valuation information after the choice of policy or process has been made. For example, valuation information is used to guide the implementation of the chosen policy or process such as setting an appropriate water use fee or pollution tax. The category "Informative" relates to the common practice of providing background information that may have an indirect influence on the decision-making process. 
Relying on the use of valuation results in decision making described by the study authors, we used our best professional judgement to place studies into the three Laurans et al. (2013) categories. For example, Mansfield et al. (2012) state:

"The U.S. Department of Interior (USDOI) desires a monetary measure of the benefits associated with a comprehensive restoration program for the Klamath River Basin in Southern Oregon and Northern California, which would accompany plans to remove a series of four large dams from the river." (page 1-1).

Mansfield et al. (2012) go on to state that economic benefit estimates will be part of the environmental and economic considerations which enter into the U.S. Secretary of the Interior's decisions related to removing dams and other actions taken to restore the Klamath River (page 11). Because of the direct use of valuation estimates by the Secretary of the Interior in the Klamath River restoration decision making process, we placed the Mansfield et al. (2012) study in the "Decisive" category. We place of the Loomis (1996) study of the benefits of dam removal on the Elwha River in the "Decisive" category for similar reasons.

Thus, whenever we were able to determine that the valuation results from a study were used directly in the decision making process, we placed that study in the "Decisive" category. If it appeared that the valuation results from a study were only used indirectly in the decision making process in a more informative role, we placed the study in the "Informative" category. If a study was conducted ex post (e.g., after a policy or management decision has been made) and it appeared the valuation results from the study were directly used to guide implementation of the decision, the study was placed in the "Technical" category. 
As can be seen in Table 4 most of the river restoration valuations reviewed fall into the "Informative" category (74\%). These studies were often undertaken as government-funded grant research to test a methodology or address an issue that has been raised in the public debate on river restoration, e.g., the effect of dam removal on property value or assessing progress towards meeting environmental quality goals. Frequently, in cases involving river restoration to recover endangered species, the US Endangered Species Act only allows a limited role for economic valuation, so naturally and formally the valuation effort is informational. In Europe, the role of economic valuation information for guiding implementation of the Water Framework Directive is also primarily information, except perhaps in the UK where the UK Environmental Agency conducted an extensive review of existing valuation studies with the intent of using these data to prioritize river restoration efforts under the Directive (Brouwer 2008).

Six of the 38 restoration valuations reviewed (16\%) were designed to be used in decisionmaking processes such as benefit-cost analysis (BCA) and policy decisions driven by the results of valuation studies such as may occur in the US under the Clean Water Act. In some cases, the connection to the final decisions can be direct and identifiable. For example, the results of the Welsh et al. (1997) study were cited in the EIS's Record of Decision by then US Secretary of the Interior Bruce Babbit as justification for incurring the opportunity cost of hydropower foregone as a result of changing water release patterns from the Glen Canyon Dam (Babbit, 1996). In most other cases, economic values were considered in the BCA, but there were a host of other factors considered, as illustrated by the US Army Corps of Engineers (1999) evaluation of the removal of the Lower Snake River dams (which did not happen) and the Loomis (1996) evaluation of the Elwha River dam removal (which did happen). 
In all six of the "Decisive" cases primary valuation methods were used. Reliance on original valuation studies is appropriate when dealing with high-cost/high-stakes (and in the two cases of dam removal, irreversible) decisions to invest in river restoration. Common in all these original studies was both the decision to do primary valuation and budget allocations being made early enough in the study process to allow time for conducting the study prior to the final decisionmaking. In the Missouri River Restoration and Recovery project, the massive scale of the Missouri River system being evaluated (1,700 river miles or 2,720 km), the large number of reservoirs and river segments involved, and the short project study time line has precluded conducting primary valuation studies.

\section{Conclusions}

Estimating the use and non-use values of river restoration has been an active area of non-market valuation for the last two decades. Part of this activity has been spurred by the need for economic valuation of river restoration associated with dam removal, something unheard of and unfathomable 30 years ago. Nearly one-half of the river restoration valuation studies we reviewed have been published in only about the last three years (2012-2015). The majority of the river restoration valuation exercises we reviewed used stated preference methods including contingent valuation and choice experiments. Stated preference methods are needed in part, if the non-use values of river restoration, such as existence values of fish and wildlife, are considered important to the decision-making process.

We estimated a simple willingness-to-pay (WTP) function, the results of which provide very preliminary evidence that the economic value of river restoration increases with the number of river miles restored (e.g., weak scope). We were not able to verify weak scope for the number of 
ecosystem goods and services since the regression coefficient on this variable was not statistically significant. Because of the very low number of observations, we do not recommend use of our regression results in "Decisive" type policy and management applications such as Benefit-Cost Analysis.

As the number of valuation studies of river restoration grows in the future, meta-analysis of these studies will become increasingly feasible and reliable. A meta-analysis of river restoration values may allow for benefit function transfer that is generally considered a more reliable form of benefit transfer (e.g., see Rolfe and Brouwer 2012). The availability of benefit function transfer will increase the potential for valuation of large and small river restoration projects. Benefit transfer may be especially useful in the case of small restoration projects where applying primary data using revealed and stated preference valuation techniques (e.g., hedonic price method; contingent valuation method) may not be cost-effective.

At this point, since most of the existing river restoration valuation studies have study sites in the US, benefit transfer based on the studies reviewed in the paper would likely be most applicable to valuing US river restoration policies and projects. Adding more river restoration valuation studies in other countries to the meta-analysis, as they become available, would broaden the international transferability of resulting benefit functions. As more river restoration valuation studies are conducted in Europe in response to the EU Water Framework Directive (e.g., Brouwer et al. 2016), international transferability of benefit functions between the North America and Europe may become feasible sooner as compared to other countries throughout the world. 


\section{References Cited}

Babbit, B. 1996. Record of Decision (ROD) Operation of Glen Canyon Dam: Final Environmental Impact Statement. October 1996. U.S. Department of Interior, Washington DC.

Bagstad, K., D. Semmens and R. Winthrop. 2013. Comparing Approaches to Spatially Explicit Ecosystem Service Modeling: A Case Study from the San Pedro River, Arizona. Ecosystem Services (5): 40-50.

Bernhardt, E., et al. (23 additional authors). 2005. Synthesizing U.S. River Restoration Efforts. Science 308: 636-637.

Berrens, R., P. Ganderton and C. Silva. 1996. Valuing the Protection of Minimum Instream Flows in New Mexico. Journal of Agricultural and Resource Economics 21(2): 294 -308

Bliem, M. and M. Getzner. 2012. Willingness-to-pay for River Restoration: Differences Across Time and Scenarios. Environmental Economics and Policy Studies 14 (3): 241-260.

Broadbent, C.D., D.S. Brookshire, D. Goodrich, M.D. Dixon, L.A. Brand, J. Thacher and S. Stewart. 2015. Valuing Preservation and Restoration Alternatives for Ecosystem Services in the Southwester USA. Ecohydrology. Published online in Wiley Online Library (wileyonlinelibrary.com) DOI: 10.1002/eco.1628

Brookshire, D., J. Chermak and R. DeSimone. 2007. Uncertainty, Benefit Transfers and Physical Models: A Middle Rio Grande Valley Focus. in S. Navrud and R. Ready (Eds.) Environmental Value Transfer: Issues and Methods. Dordrecht, The Netherlands: Springer. pp. 89-109.

Brouwer, R. 2008. The Role of Stated Preference Methods in the Water Framework Directive to Assess Disproportionate Costs. Journal of Environmental Planning and Management, 51(5): 597-614.

Brouwer. R., M. Bliem, M. Getzner, S. Kerekes, S. Milton, T. Palarie, Z. Szerényi, A. Vadineanu, and A. Wagtendonk. 2016. Valuation and Transferability of the Non-Market Benefits of River Restoration in the International Danube River Basin Using a Choice Experiment. Ecological Engineering, 87: 20-29. doi:10.1016/j.ecoleng.2015.11.018

Brown, T., J. Bergstrom and J. Loomis. 2007. Defining, Valuing, and Providing Ecosystem Goods and Service. Natural Resources Journal, 47(2): 331- 376.

Collins, A., R. Rosenberger, and J. Fletcher. 2005. The Economic Value of Stream Restoration. Water Resources Research, 41(2): W02017, DOI: 10.1029/2004WR003353.

Daily, G.C. 1997. Introduction: What Are Ecosystem Services? in G.C. Daily (ed.) Nature's Services: Societal Dependence on Natural Ecosystems, Washington, D.C.: Island Press. 
Dubgaard, A., M. Kallesoe, J. Ladenburg, J. and M. Petersen. 2005. Cost-Benefit Analysis of the Skjern River Restoration in Denmark. In R. Brouwer and D. Pearce (Eds.) Cost-Benefit Analysis and Water Resources Management, Cheltenham, U.K. and Northampton, Mass.: Elgar.

ECa (http://ec.europa.eu/environment/pubs/pdf/factsheets/water-framework-directive.pdf accessed December, 2015)

$\mathrm{ECb}$ (http://eur-lex.europa.eu/legalcontent/EN/TXT/PDF/?uri=CELEX:52012DC0670\&from=EN accessed December 2015)

Gibbs, J. 2013. Appendix V.7. UGLAA Appendix V.7. Missouri River Recovery Program Integrated Science Program.

Giraud, K., J. Loomis and R. Johnson. 1999. Internal and External Scope in Willingness-to-Pay Estimates for Threatened and Endangered Wildlife. Journal of Environmental Management, 56(3): 221-229.

Hanley, N., R. Wright and B. Alvarez-Farizo. 2006. Estimating the Economic Value of Improvements in River Ecology Using Choice Experiments: An Application to the Water Framework Directive. Journal of Environmental Management, 78(2): 183-193.

Hanley, N., D. MacMillan, R.E. Wright, C. Bullock, I. Simpson, D. Parisson and B. Crabtree, 1998. Contingent Valuation Versus Choice Experiments: Estimating the Benefits of Environmentally Sensitive Areas in Scotland. Journal of Agricultural Economics, 49(1): 1-15.

Holmes, T., J. Bergstrom, E. Huszar, S. Kask and F. Orr. 2004. Contingent Valuation, Net Marginal Benefits and the Scale of Riparian Ecosystem Restoration. Ecological Economics, 49: 19-30.

Honey-Roses, J. 2013. Examining the Demand for Ecosystem Services: The Value of Stream Restoration for Drinking Water Treatment Managers in the Llobregat River, Spain. Ecological Economics, (90): 196-205.

Johnston, R., K. Segerson, R. Schultz, E. Besedin and M. Ramachandran. 2011. Indices of Biotic Integrity in Stated Preference Valuation Aquatic Ecosystem Services. Ecological Economics, 70(11): 1946-1956.

Kenney, M., P. Wilcock, B. Hobbs, N. Flores and D. Martínez. 2012. Is Urban Stream Restoration Worth It? Journal of the American Water Resources Association, 48(3): 603-615.

Kristensen, P. and H.O. Hansen. 1994. European Rivers and Lakes: Assessment of their Environmental State. EAA Environmental Monographs 1. European Environmental Agency. Copenhagen. 
Laurans, Y., A., Rankovic, R. Bille, R. Pirard and L. Mermet. 2013. Use of Ecosystem Services Economic Valuation for Decision Making: Questioning a Literature Blindspot. Journal of Environmental Management, 119: 208-219.

Lew, D. and K. Wallmo. 2011. External Tests of Scope and Embedding in Stated Preference Choice Experiments: An Application to Endangered Species Valuation. Environmental and Resource Economics, 48: 1-23.

Lewis, L., C. Bohlen and S. Wilson. 2008. Dams, Dam Removal and River Restoration: A Hedonic Property Value Analysis. Contemporary Economic Policy, 26(2): 175-186.

Loomis, J. 1996. Measuring the Economic Benefits of Removing Dams and Restoring the Elwha River: Results of a Contingent Valuation Survey. Water Resources Research, 32(2): 441-447.

Loomis, J., P. Kent, L. Strange, K. Fausch and A. Covich. 2000. Measuring the Total Economic Value of Restoring Ecosystem Services in an Impaired River Basin: Results from a Contingent Valuation Survey. Ecological Economics, 33: 103-117.

Makombe, T. 2003. Evaluation of Economic Benefits and Impacts of the Proposed Removal of the Marion Dam in Osceola County, Michigan. M.S. Thesis. Dept. of Agricultural Economics, Michigan State University, East Lansing, MI.

Mansfield, C., G. Van Houtven, A. Hendershott, P. Chen, J. Porter, V. Nourani, and V. Kilambi. 2012. Klamath River Basin Restoration Nonuse Value Survey. Research Triangle Park, NC.

Meyer, A. 2013. Intertemporal Valuation of River Restoration. Environmental and Resource Economics, 54(1): 41-61.

Mitchell, R. and R. Carson. 1989. Using Surveys to Value Public Goods: The Contingent Valuation Method. Resources for the Future, Washington DC.

National Water Commission. 2009. A National Synthesis of River Restoration Projects. Australian Government. November 2009.

Ojeda, M., A. Mayer and B. Solomon. 2007. Economic Valuation of Environmental Services Sustained by Water Flows in the Yaqui River Delta. Ecological Economics, 65(1): 155-166.

Patton, D., J. Bergstrom, A. Covich, and R. Moore. 2012 (revised 2013). National Wildlife Refuge Wetland Ecosystem Service Valuation Model, Phase 1A Final Report: An Assessment of Ecosystem Services Associated with National Wildlife Refuges. Prepared for Division of Economics and Division of Refuges, Cooperative Ecosystem Studies Unit (Piedmont), U.S. Fish and Wildlife Service, Washington, DC. 
Patton, D., J.C. Bergstrom, R. Moore and A.P. Covich. 2015. Economic Value of Carbon Storage in U.S. National Wildlife Refuge Wetland Ecosystems. Ecosystem Services, 16 (December): 94-104.

Paulrud, A. and T. Laitila. 2013. A Cost-Benefit Analysis of Restoring the Em River in Sweden: Valuation of Angling Site Characteristics and Visitation Frequency. Applied Economics, 45(1618): 2255-2266.

Provencher, B., H. Sarakinos, and T. Meyer. 2008. Does Small Dam Removal Affect Local Property Values: An Empirical Analysis. Contemporary Economic Policy, 26(2): 187-197.

Richardson, L. and J. Loomis. 2009. The Total Economic Value of Threatened, Endangered and Rare Species: An Updated Meta-Analysis, Ecological Economics, 68: 1535-1548.

Roe, B., K. Boyle, and M. Teisl. 1996. Using Conjoint Analysis to Derive Estimates of Compensating Variation. Journal of Environmental Economics and Management, 31: 145-59.

Rolfe, J. and R. Brouwer, R. 2012. Design Effects in a Meta-Analysis of River Health Choice Experiments in Australia. Journal of Choice Modelling, 5(2): 81-97.

Stratus Consulting. 2015. Economic Valuation of Restoration Actions for Salmon and Forests and Associated Wildlife in and along the Elwha River. Stratus Consulting Inc., Boulder, CO

US Army Corps of Engineers. Lower Snake River Juvenile Salmon Migration Feasibility Report/ Environmental Impact Statement. Walla Walla District.

http://www.nww.usace.army.mil/Library/2002LSRStudy.aspx

US EPAa (http://water.epa.gov/type/rsl/ accessed December, 2015)

US EPAb (http://www2.epa.gov/tmdl accessed December 2015)

US EPAc (http://www2.epa.gov/sfbay-delta/sf-bay-water-quality-improvement-fund accessed December 2015)

US FWS (http://www.fws.gov/fisheries/pdfs/Programs/NRDAR_Program_2-10-05.pdf accessed December 2015)

US NRCS (http://www.nrcs.usda.gov/wps/portal/nrcs/main/national/programs/ accessed December, 2015)

Van Bueren, M. and J. Bennett 2004. Towards the Development of a Transferable Set of Value Estimates for Environmental Attributes. Australian Journal of Agricultural and Resource Economics, 48(1): 1-32. 
Vermaat, J.E. et al. (18 additional authors).j 2015. Assessing the Societal Benefits of River Restoration Using the Ecosystem Services Approach. Hydrobiologia, 769: 121-135. DOI 10.1007/s10750-015-2482-z

Vorosmarty, C., B. Fekete, M. Meybeck, R. Lammers. 2000. Global System of Rivers: Its Role in Organizing Continental Land Mass and Defining Land-to-Ocean Linkages. Global Biogeochemical Cycles, 14(2): 599-621.

Weber, M. 2015. Who Cares About the Santa Cruz River? Presentation prepared for Arizona Hydrological Society, Santa Cruz River Stakeholders Meeting, December, Tucson, Arizona.

Weber, M. and S. Stewart 2008. Public Values for River Restoration Option on the Middle Rio Grande. Restoration Ecology, 17(6): 762-771.

Welsh, M., R. Bishop, M. Phillips, R. Baumgartner. 1997. Glen Canyon Dam, Colorado River Storage Project, Arizona. Final Use Value Study Summary Report. EC-97-09. U.S. Bureau of Reclamation, Salt Lake City, UT. Available from NTIS as PB98-106636.

Zhao, M., R. Johnston and E. Schultz. 2013. What to Value and How? Ecological Indicator Choices in Stated Preference Valuation. Environmental and Resource Economics, 56(1): 3-25.

Zhongmin, X., C. Guodong, Z. Zhiqiang, S. Zhiyong, and J. Loomis. 2003. Applying Contingent Valuation in China to Measure the Total Economic Value of Restoring Ecosystem Services in Ejina Region. Ecological Economics, 44: 345-358. 
Table 1. Summary of Ecosystem Good and Service Goals of River Restoration

\begin{tabular}{|c|c|c|c|c|c|c|c|c|c|c|c|c|}
\hline Authors & "River & $\begin{array}{l}\text { USA } \\
\text { State or } \\
\text { Other } \\
\text { Country }\end{array}$ & 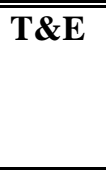 & Fish & Wildlife & Boating & Fishing & "Swim & Drinkable & Aesthetics & $\begin{array}{l}\text { Climate } \\
\text { Regulation }\end{array}$ & $\begin{array}{l}\text { Flood } \\
\text { Regulation }\end{array}$ \\
\hline $\begin{array}{l}\text { 1) Bagstad et al. } \\
2013\end{array}$ & San Pedro & $\mathrm{AZ}$ & 0 & 0 & 0 & 0 & 0 & 0 & 0 & 0 & 1 & 0 \\
\hline $\begin{array}{l}\text { 2) Berrens et al. } \\
1996\end{array}$ & Rio Grande & NM & 1 & 1 & 0 & 0 & 0 & 0 & 0 & 0 & 0 & 0 \\
\hline $\begin{array}{l}\text { 3)Bliem and } \\
\text { Getzner } 2012\end{array}$ & Danube & AUT & 0 & 1 & 1 & 0 & 0 & 0 & 0 & 0 & 0 & 1 \\
\hline $\begin{array}{l}\text { 4) Broadbent et } \\
\text { al. } 2015\end{array}$ & San Pedro & $\mathrm{AZ}$ & 0 & 0 & 1 & 0 & 0 & 0 & 0 & 0 & 0 & 0 \\
\hline $\begin{array}{l}\text { 5) Broadbent et } \\
\text { al. } 2015\end{array}$ & Rio Grande & NM & 0 & 0 & 1 & 0 & 0 & 0 & 0 & 0 & 0 & 0 \\
\hline $\begin{array}{l}\text { 6) Brookshire et } \\
\text { al. } 2007\end{array}$ & Rio Grande & NM & 1 & 0 & 1 & 0 & 0 & 0 & 0 & 0 & 0 & 0 \\
\hline $\begin{array}{l}\text { 7) Brouwer et al. } \\
2016\end{array}$ & Danube & AUT & 0 & 0 & 0 & 1 & 1 & 0 & 0 & 0 & 0 & 1 \\
\hline $\begin{array}{l}\text { 8) Brouwer et al. } \\
2016\end{array}$ & Danube & HUN & 0 & 0 & 0 & 1 & 1 & 0 & 0 & 0 & 0 & 1 \\
\hline $\begin{array}{l}\text { 9) Brouwer et al. } \\
2016\end{array}$ & Danube & ROM & 0 & 0 & 0 & 1 & 1 & 0 & 0 & 0 & 0 & 1 \\
\hline $\begin{array}{l}\text { 10) Collins et al. } \\
2005\end{array}$ & $\begin{array}{l}\text { Deckers } \\
\text { Creek }\end{array}$ & $\mathrm{WV}$ & 0 & 1 & 0 & 0 & 1 & 0 & 0 & 1 & 0 & 0 \\
\hline $\begin{array}{l}\text { 11) Dubgaard et } \\
\text { al. } 2005\end{array}$ & Skjern & DNK & 0 & 1 & 1 & 0 & 1 & 0 & 0 & 0 & 0 & $\overline{0}$ \\
\hline $\begin{array}{l}\text { 12) Dubgaard et } \\
\text { al. } 2005\end{array}$ & Skjern & DNK & 1 & 1 & 0 & 1 & 1 & 1 & 0 & 0 & 0 & 0 \\
\hline 13) Gibbs 2013 & Missouri & $\mathrm{MO}$ & 1 & 1 & 1 & 1 & 1 & 0 & 0 & 0 & 0 & $\overline{0}$ \\
\hline $\begin{array}{l}\text { 14) Hanley et al. } \\
2006\end{array}$ & Wear & GBR & 0 & 1 & 1 & 0 & 1 & 0 & 0 & 1 & 0 & 0 \\
\hline $\begin{array}{l}\text { 15) Hanley et al. } \\
2006\end{array}$ & Clyde & GBR & 0 & 1 & 1 & 0 & 1 & 0 & 0 & 1 & 0 & $\overline{0}$ \\
\hline $\begin{array}{l}\text { 16) Holmes et al. } \\
2004\end{array}$ & $\begin{array}{l}\text { Little } \\
\text { Tennessee }\end{array}$ & $\mathrm{NC}$ & 0 & 1 & 1 & 1 & 1 & 0 & 1 & 0 & 0 & 0 \\
\hline $\begin{array}{l}\text { 17) Honey-Roses } \\
\text { et al. } 2013\end{array}$ & Llobregat & ESP & 0 & 1 & 1 & 0 & 1 & 0 & 0 & 0 & 0 & 0 \\
\hline $\begin{array}{l}\text { 18) Johnston et } \\
\text { al. } 2011\end{array}$ & Pawtuxet & RI & 0 & 1 & 1 & 0 & 1 & 0 & 0 & 0 & 0 & 0 \\
\hline $\begin{array}{l}\text { 19) Kenney et al. } \\
2012\end{array}$ & $\begin{array}{l}\text { urban } \\
\text { streams }\end{array}$ & MD & 0 & 0 & 0 & 0 & 1 & 0 & 0 & 1 & 0 & 0 \\
\hline
\end{tabular}




\begin{tabular}{|c|c|c|c|c|c|c|c|c|c|c|c|c|}
\hline $\begin{array}{l}\text { 20) Lewis et al. } \\
2008\end{array}$ & Kennebec & $\mathrm{ME}$ & 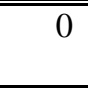 & 1 & 0 & 1 & 1 & 0 & 0 & 1 & 0 & 0 \\
\hline 21) Loomis 1996 & Elwha & WA & 1 & 1 & 0 & 0 & 0 & 0 & 0 & 0 & 0 & 0 \\
\hline $\begin{array}{l}\text { 22) Loomis et al. } \\
2000\end{array}$ & South Platte & $\mathrm{CO}$ & 0 & 1 & 0 & 1 & 1 & 0 & 0 & 0 & 0 & 0 \\
\hline $\begin{array}{l}\text { 23) Makombe } \\
2003\end{array}$ & $\begin{array}{l}\text { Middle } \\
\text { Branch }\end{array}$ & MI & 0 & 1 & 0 & 0 & 0 & 0 & 0 & 0 & 0 & 0 \\
\hline $\begin{array}{l}\text { 24) Mansfield et } \\
\text { al. } 2012\end{array}$ & Klamath & OR & 1 & 1 & 0 & 0 & 1 & 0 & 0 & 0 & 0 & 0 \\
\hline 25) Meyer 2013 & Minnesota & $\mathrm{MN}$ & 0 & 1 & 1 & 1 & 1 & 1 & 0 & 0 & 0 & 0 \\
\hline $\begin{array}{l}\text { 26) Ojeda et al. } \\
2007\end{array}$ & Yaqui & MEX & 0 & 1 & 1 & 1 & 1 & 0 & 0 & 0 & 0 & 0 \\
\hline $\begin{array}{l}\text { 27) Patton et al. } \\
2015\end{array}$ & Rio Grande & NM & 0 & 0 & 0 & 0 & 0 & 0 & 0 & 0 & 1 & 0 \\
\hline $\begin{array}{l}\text { 28) Patton et al. } \\
2012\end{array}$ & Rio Grande & NM & 0 & 0 & 0 & 1 & 1 & 0 & 0 & 0 & 0 & 0 \\
\hline $\begin{array}{l}\text { 29) Paulrud and } \\
\text { Laitila } 2013\end{array}$ & $\mathrm{Em}$ & SWE & 0 & 1 & 0 & 0 & 1 & 0 & 0 & 0 & 0 & 0 \\
\hline $\begin{array}{l}\text { 30) Provencher } \\
\text { et al. } 2008 \\
\end{array}$ & Wisconsin & WI & 0 & 0 & 0 & 1 & 1 & 0 & 0 & 1 & 0 & 0 \\
\hline 31) Stratus 2015 & Elwha & $\mathrm{WA}$ & 0 & 1 & 1 & 0 & 1 & 0 & 0 & 0 & 0 & 0 \\
\hline 32) Weber 2015 & Santa Cruz & $\mathrm{AZ}$ & 0 & 0 & 0 & 0 & 0 & 1 & 0 & 0 & 0 & 0 \\
\hline $\begin{array}{l}\text { 33) Weber and } \\
\text { Stewart (2008) }\end{array}$ & $\begin{array}{l}\text { Middle Rio } \\
\text { Grande }\end{array}$ & $\mathrm{NM}$ & 0 & 1 & 1 & 0 & 0 & 0 & 0 & 0 & 0 & 0 \\
\hline $\begin{array}{l}\text { 34) Weber and } \\
\text { Stewart } 2008 \\
\end{array}$ & $\begin{array}{l}\text { Middle Rio } \\
\text { Grande }\end{array}$ & NM & 0 & 1 & 1 & 0 & 0 & 0 & 0 & 0 & 0 & 0 \\
\hline $\begin{array}{l}\text { 35) Welsh et al. } \\
1997\end{array}$ & Colorado & $\overline{A Z}$ & 1 & 1 & 1 & 1 & 1 & 0 & 0 & 0 & 0 & 0 \\
\hline $\begin{array}{l}\text { 36) U.S. Army } \\
\text { Corps of } \\
\text { Engineers } 1999\end{array}$ & Snake & ID & 1 & 1 & 0 & 1 & 1 & 0 & 0 & 0 & 0 & 0 \\
\hline $\begin{array}{l}\text { 37) Zhao et al. } \\
2013\end{array}$ & Pawtuxet & RI & 0 & 1 & 1 & 0 & 1 & 0 & 0 & 0 & 0 & 0 \\
\hline $\begin{array}{l}\text { 38) Zhongmin et } \\
\text { al. } 2003\end{array}$ & Hei & $\mathrm{CHN}$ & 0 & 1 & 1 & 0 & 0 & 0 & 0 & 0 & 0 & 0 \\
\hline Summary & & & $21 \%$ & $68 \%$ & $50 \%$ & $39 \%$ & $63 \%$ & $13 \%$ & $3 \%$ & $16 \%$ & $5 \%$ & $11 \%$ \\
\hline
\end{tabular}


Table 2. WTP Per Household from CVM and CE Studies (2015 USD)

\begin{tabular}{|c|c|c|c|c|c|}
\hline Authors & $\begin{array}{l}\text { Annual WTP } \\
\text { Per Household } \\
\text { (valuation } \\
\text { method) }\end{array}$ & $\begin{array}{l}\text { Restored } \\
\text { River Miles } \\
\text { (Kilometers) }\end{array}$ & $\begin{array}{l}\text { Annual } \\
\text { WTP Per } \\
\text { Household } \\
\text { Per Mile of } \\
\text { River } \\
\text { Restored }\end{array}$ & $\begin{array}{l}\text { Annual } \\
\text { WTP Per } \\
\text { Household } \\
\text { Per } \\
\text { Kilometer } \\
\text { of River } \\
\text { Restored }\end{array}$ & $\begin{array}{l}\text { Number of } \\
\text { Ecosystem } \\
\text { Goods and } \\
\text { Services } \\
\text { Valued }\end{array}$ \\
\hline $\begin{array}{l}\text { 1) Berrens et al. } \\
1996\end{array}$ & $\$ 43(\mathrm{CVM})$ & $170(272)$ & $\$ 0.25$ & $\$ 0.16$ & 2 \\
\hline $\begin{array}{l}\text { 2) Bliem and } \\
\text { Getzner } 2012\end{array}$ & 38 (CVM) & $24(38)$ & 1.60 & 1.00 & 3 \\
\hline $\begin{array}{l}\text { 3) Broadbent et } \\
\text { al. } 2015\end{array}$ & $51(\mathrm{CVM})$ & $40(64)$ & 1.28 & 0.80 & 1 \\
\hline $\begin{array}{l}\text { 4) Broadbent et } \\
\text { al. } 2015\end{array}$ & $62(\mathrm{CVM})$ & $80(128)$ & 0.78 & 0.48 & 1 \\
\hline $\begin{array}{l}\text { 5) Brouwer et al. } \\
2016 \text { - AUT }\end{array}$ & $127(\mathrm{CE})$ & $22(35)$ & 5.77 & 3.63 & 2 \\
\hline $\begin{array}{l}\text { 6) Brouwer et al. } \\
2016 \text { - HUN }\end{array}$ & $37(\mathrm{CE})$ & $31(50)$ & 1.19 & 0.74 & 2 \\
\hline $\begin{array}{l}\text { 7) Brouwer et al. } \\
2016 \text { - ROM }\end{array}$ & $55(\mathrm{CE})$ & $121(195)$ & 0.46 & 0.28 & 2 \\
\hline $\begin{array}{l}\text { 8) Collins et al. } \\
2005\end{array}$ & $190(\mathrm{CE})$ & $24(38)$ & 8 & 5 & 3 \\
\hline $\begin{array}{l}\text { 9) Holmes et al. } \\
2004\end{array}$ & 34 (CVM) & $6(10)$ & 5.67 & 3.40 & 5 \\
\hline $\begin{array}{l}\text { 10) Kenney et } \\
\text { al. } 2012\end{array}$ & $3(\mathrm{CVM})$ & $0.25(0.40)$ & 12 & 8 & 2 \\
\hline $\begin{array}{l}\text { 11) Loomis } \\
1996\end{array}$ & 109 (CVM) & 70 (112) & 1.56 & 0.97 & 1 \\
\hline $\begin{array}{l}\text { 12) Loomis et al. } \\
2000\end{array}$ & 29 (CVM) & $45(72)$ & 0.64 & 0.40 & 2 \\
\hline $\begin{array}{l}\text { 13) Mansfield et } \\
\text { al. } 2012\end{array}$ & $220(\mathrm{CE})$ & $120(192)$ & 1.82 & 1.14 & 3 \\
\hline $\begin{array}{l}\text { 14) Ojeda et al. } \\
2007\end{array}$ & 22 (CVM) & Not specified & N/A & N/A & 4 \\
\hline $\begin{array}{l}\text { 15) Weber and } \\
\text { Stewart } 2008\end{array}$ & 55 (CVM) & $17(27)$ & 3.24 & 2.04 & 2 \\
\hline $\begin{array}{l}\text { 16) Weber and } \\
\text { Stewart } 2008\end{array}$ & $173(\mathrm{CE})$ & $17(27)$ & 10.18 & 6.41 & 2 \\
\hline $\begin{array}{l}\text { 17) Welsh et al. } \\
1997\end{array}$ & 169 (CVM) & $300(480)$ & 0.56 & 0.35 & 5 \\
\hline $\begin{array}{l}\text { 18) Zhongmin et } \\
\text { al. } 2003\end{array}$ & $4(\mathrm{CVM})$ & Not specified & N/A & N/A & 2 \\
\hline
\end{tabular}


Table 3. WTP for River Restoration: Ordinary Least Squares Regression Results

\begin{tabular}{|c|c|}
\hline Explanatory Variable & Coefficient Estimate (standard error) \\
\hline Miles of Restoration Valued & $.4783(.2106) *$ \\
\hline Number of Ecosystem Goods and Services Valued & $36.21(49.05)$ \\
\hline $\begin{array}{l}\text { Valuation Method }(0=\text { contingent valuation method } \\
1=\text { choice experiment })\end{array}$ & $88.64(52.89)$ \\
\hline Country $(0=$ U.S.A.; $1=$ other $)$ & $-49.12(42.10)$ \\
\hline \multicolumn{2}{|c|}{ Dependent variable = annual willingness-to-pay $(\mathrm{WTP})$ per household for river restoration } \\
\hline R-Squared $=.14$ & \\
\hline
\end{tabular}


Table 4. Valuation Methods and Role in Decision Making

\begin{tabular}{|c|c|c|c|c|c|}
\hline \multirow[b]{2}{*}{ Authors } & \multirow[b]{2}{*}{ River } & \multirow{2}{*}{$\begin{array}{l}\text { Valuation } \\
\text { Method }\end{array}$} & \multicolumn{3}{|c|}{ Role in Decision Making } \\
\hline & & & Decisive & Technical & Informative \\
\hline 1) Bagstad et al. 2013 & San Pedro & SIM & 0 & 0 & 1 \\
\hline 2) Berrens et al. 1996 & Rio Grande & CVM & 0 & 0 & 1 \\
\hline $\begin{array}{l}\text { 3) Bliem and Getzner } \\
2012\end{array}$ & Danube & CVM & 0 & 0 & 1 \\
\hline $\begin{array}{l}\text { 4) Broadbent et al. } \\
2015\end{array}$ & San Pedro & CVM & 0 & 0 & 1 \\
\hline $\begin{array}{l}\text { 5) Broadbent et al. } \\
2015\end{array}$ & Rio Grande & CVM & 0 & 0 & 1 \\
\hline $\begin{array}{l}\text { 6) Brookshire et al. } \\
2007\end{array}$ & Rio Grande & $\mathrm{CE}$ & 0 & 0 & 1 \\
\hline $\begin{array}{l}\text { 7) Brouwer et al. } \\
2016\end{array}$ & Danube, Austria & $\mathrm{CE}$ & 0 & 0 & 1 \\
\hline $\begin{array}{l}\text { 8) Brouwer et al. } \\
2016\end{array}$ & Danube, Hungary & $\mathrm{CE}$ & 0 & 0 & 1 \\
\hline $\begin{array}{l}\text { 9) Brouwer et al. } \\
2016\end{array}$ & Danube, Romania & $\mathrm{CE}$ & 0 & 0 & 1 \\
\hline $\begin{array}{l}\text { 10) Collins et al. } \\
2005\end{array}$ & Deckers Creek & $\mathrm{CE}$ & 0 & 0 & 1 \\
\hline $\begin{array}{l}\text { 11) Dubgaard et al. } \\
2003\end{array}$ & Skjern & $\mathrm{RC}$ & 1 & 0 & 0 \\
\hline $\begin{array}{l}\text { 12) Dubgaard et al. } \\
2003\end{array}$ & Skjern & BT & 0 & 1 & 0 \\
\hline 13) Gibbs 2015 & Missouri River & $\mathrm{BT}$ & 0 & 1 & 0 \\
\hline $\begin{array}{l}\text { 14) Hanley et al. } \\
2006\end{array}$ & Wear & $\mathrm{CE}$ & 0 & 0 & 1 \\
\hline $\begin{array}{l}\text { 15) Hanley et al. } \\
2006\end{array}$ & Clyde & $\mathrm{CE}$ & 0 & 0 & 1 \\
\hline $\begin{array}{l}\text { 16) Holmes et al. } \\
2004\end{array}$ & Little Tennessee & CVM & 0 & 0 & 1 \\
\hline $\begin{array}{l}\text { 17) Honey-Roses et } \\
\text { al. } 2013\end{array}$ & Llobregat & $\mathrm{RC}$ & 0 & 0 & 1 \\
\hline $\begin{array}{l}\text { 18) Johnston et al. } \\
2011\end{array}$ & Pawtuxet & $\mathrm{CE}$ & 0 & 0 & 1 \\
\hline $\begin{array}{l}\text { 19) Kenney et al. } \\
2012\end{array}$ & urban streams & MD & 1 & 0 & 0 \\
\hline 20) Lewis, et al. 2008 & Kennebec & HPM & 0 & 0 & 1 \\
\hline 21) Loomis 1996 & Elwha & CVM & 1 & 0 & 0 \\
\hline $\begin{array}{l}\text { 22) Loomis et al. } \\
2000\end{array}$ & South Platte & $\mathrm{CVM}$ & 0 & 0 & 1 \\
\hline 23) Makombe 2003 & Middle Branch & TCM & 0 & 0 & 1 \\
\hline $\begin{array}{l}\text { 24) Mansfield et al. } \\
2012\end{array}$ & Klamath & $\mathrm{CE}$ & 1 & 0 & 0 \\
\hline 25) Meyer 2012 & Minnesota & $\mathrm{MN}$ & 0 & 0 & 1 \\
\hline 26) Ojeda et al. 2007 & Yaqui & CVM & 0 & 0 & 1 \\
\hline 27) Patton et al. 2015 & Rio Grande & SIM & 0 & 0 & 1 \\
\hline 28) Patton et al. 2012 & Rio Grande & $\mathrm{BT}$ & 0 & 0 & 1 \\
\hline $\begin{array}{l}\text { 29) Paulrud and } \\
\text { Laitila } 2013\end{array}$ & Em & $\mathrm{CE}$ & 1 & 0 & 0 \\
\hline $\begin{array}{l}\text { 30) Provencher et al. } \\
2008\end{array}$ & Wisconsin & HPM & 0 & 0 & 1 \\
\hline
\end{tabular}




\begin{tabular}{||l|l|l|r|r|r||}
\hline 31) Stratus 2015 & Elwha & CE & 0 & 1 & 0 \\
\hline 32) Weber 2013 & Santa Cruz & CE & 0 & 0 & 1 \\
\hline $\begin{array}{l}\text { 33) Weber and } \\
\text { Stewart 2009 }\end{array}$ & Middle Rio Grande & CE & 0 & 0 & 1 \\
\hline $\begin{array}{l}\text { 34) Weber and } \\
\text { Stewart 2009 }\end{array}$ & Middle Rio Grande & CVM & 0 & 0 & 0 \\
\hline 35) Welsh, et al. 1997 & Colorado & CVM & 1 & 0 & 0 \\
\hline $\begin{array}{l}\text { 36) U.S. Army Corps } \\
\text { of Engineers 1999 }\end{array}$ & Snake River & TCM & 1 & 0 & 1 \\
\hline 37) Zhao et al. 2013 & Pawtuxet & CE & 0 & 0 & 0 \\
\hline $\begin{array}{l}\text { 38) Zhongmin et al. } \\
\text { 2003 }\end{array}$ & Hei & CVM & 0 & $6(16 \%)$ & $4(10 \%)$ \\
\hline Totals & & & $28(74 \%)$ \\
\hline
\end{tabular}

*BT is benefit transfer; CVM is contingent valuation method; HPM is hedonic property method; CE is choice experiment; TCM is travel cost method; SIM is simulation model; RC is replacement cost. 
Table A1. Marginal Value Estimates from Choice Experiments for River Restoration Attributes

\begin{tabular}{|c|c|c|c|}
\hline Authors and River & River Restoration Attribute & Attribute Levels & $\begin{array}{c}\text { Marginal Value } \\
\text { (2015 USD) }\end{array}$ \\
\hline $\begin{array}{l}\text { Brouwer et al. 2016, } \\
\text { Danube River, AUT }\end{array}$ & Flood frequency (return period) & $\begin{array}{l}\text { once every } 5,25, \text { or } 50 \\
\text { years }\end{array}$ & $\$ 0.22$ \\
\hline $\begin{array}{l}\text { Brouwer et al. 2016, } \\
\text { Danube River, AUT }\end{array}$ & Good water quality & moderate, good, very good & $\$ 55$ \\
\hline $\begin{array}{l}\text { Brouwer et al. 2016, } \\
\text { Danube River, AUT }\end{array}$ & Very good water quality & moderate, good, very good & $\$ 70$ \\
\hline $\begin{array}{l}\text { Brouwer et al. 2016, } \\
\text { Danube River, HUN }\end{array}$ & Flood frequency (return period) & $\begin{array}{l}\text { once every } 5,25 \text {, or } 50 \\
\text { years }\end{array}$ & $\$ 0.02$ \\
\hline $\begin{array}{l}\text { Brouwer et al. 2016, } \\
\text { Danube River, HUN }\end{array}$ & Good water quality & moderate, good, very good & $\$ 9$ \\
\hline $\begin{array}{l}\text { Brouwer et al. 2016, } \\
\text { Danube River, HUN }\end{array}$ & Very good water quality & moderate, good, very good & $\$ 19$ \\
\hline $\begin{array}{l}\text { Brouwer et al. 2016, } \\
\text { Danube River, ROU }\end{array}$ & Flood frequency (return period) & $\begin{array}{l}\text { once every } 5,25 \text {, or } 50 \\
\text { years }\end{array}$ & $\$-0.03$ \\
\hline $\begin{array}{l}\text { Brouwer et al. 2016, } \\
\text { Danube River, ROU }\end{array}$ & Good water quality & moderate, good, very good & 8 \\
\hline $\begin{array}{l}\text { Brouwer et al. 2016, } \\
\text { Danube River, ROU }\end{array}$ & Very good water quality & moderate, good, very good & 18 \\
\hline $\begin{array}{l}\text { Collins et al. 2005, } \\
\text { Deckers Creek }\end{array}$ & Aquatic life including fish & low, moderate, high & $\$ 6$ \\
\hline $\begin{array}{l}\text { Collins et al. 2005, } \\
\text { Deckers Creek }\end{array}$ & Safe swimming and wading & low, moderate, high & $\$ 4$ \\
\hline $\begin{array}{l}\text { Collins et al. 2005, } \\
\text { Deckers Creek }\end{array}$ & Aesthetic quality & low, moderate, high & $\$ 5$ \\
\hline $\begin{array}{l}\text { Hanley et al. 2006, } \\
\text { River Clyde }\end{array}$ & Quantity of fish \& wildlife & good, fair & $\$ 85$ \\
\hline $\begin{array}{l}\text { Hanley et al. 2005, } \\
\text { River Wear }\end{array}$ & Quantity of fish \& wildlife & good, fair & $\$ 26$ \\
\hline $\begin{array}{l}\text { Hanley et al. 2006, } \\
\text { River Clyde }\end{array}$ & Aesthetic quality & good, fair & $\$ 64$ \\
\hline $\begin{array}{l}\text { Hanley et al. 2005, } \\
\text { River Wear }\end{array}$ & Aesthetic quality & good, fair & $\$ 26$ \\
\hline $\begin{array}{l}\text { Hanley et al. 2006, } \\
\text { River Clyde }\end{array}$ & $\begin{array}{l}\text { Quantity of bank vegetation and soil } \\
\text { stability }\end{array}$ & good, fair & $\$ 94$ \\
\hline $\begin{array}{l}\text { Hanley et al. 2005, } \\
\text { River Wear }\end{array}$ & $\begin{array}{l}\text { Quantity of bank vegetation and soil } \\
\text { stability }\end{array}$ & good, fair & $\$ 28$ \\
\hline $\begin{array}{l}\text { Johnston et al. 2011, } \\
\text { Pawtuxet River }\end{array}$ & $\begin{array}{l}\text { Acres of river habitat accessible to } \\
\text { migratory fish (as a percentage of the } \\
\text { reference value for the watershed) }\end{array}$ & $\begin{array}{l}0 \%(0 \text { acres }), 5 \%(225 \\
\text { acres }), 10 \%(450 \text { acres }), \\
20 \%(900 \text { acres })\end{array}$ & $\$ 0.78$ \\
\hline $\begin{array}{l}\text { Johnston et al. 2011, } \\
\text { Pawtuxet River }\end{array}$ & $\begin{array}{l}\text { Probability, in percentage terms, that } \\
\text { migratory species will migrate the river in } \\
50 \text { years }\end{array}$ & $0 \%, 30 \%, 50 \%, 70 \%$ & $\$ 0.30$ \\
\hline $\begin{array}{l}\text { Johnston et al. 2011, } \\
\text { Pawtuxet River }\end{array}$ & $\begin{array}{l}\text { Accessibility of restored area for public } \\
\text { walking and fishing }\end{array}$ & Accessible, Not accessible & $\$ 21$ \\
\hline $\begin{array}{l}\text { Johnston et al. 2011, } \\
\text { Pawtuxet River }\end{array}$ & $\begin{array}{l}\text { Similarity, in percentage terms, of aquatic } \\
\text { ecological quality to the most undisturbed } \\
\text { watershed in Rhode Island }\end{array}$ & $65 \%, 70 \%, 75 \%, 80 \%$ & $\$ 0.79$ \\
\hline $\begin{array}{l}\text { Johnston et al. 2011, } \\
\text { Pawtuxet River }\end{array}$ & $\begin{array}{l}\text { Quantity of fish-eating wildlife species, in } \\
\text { percentage terms, that are common in } \\
\text { restored areas }\end{array}$ & $\begin{array}{l}55 \%(20 \text { species }) \\
60 \%(22), 70 \%(25 \\
\text { species }), 80 \%(28 \text { species })\end{array}$ & $\$ 0.58$ \\
\hline $\begin{array}{l}\text { Johnston et al. 2011, } \\
\text { Pawtuxet River }\end{array}$ & $\begin{array}{l}\text { Quantity of catchable-size fish in restored } \\
\text { areas, measured as the number of fish per } \\
\text { hour caught by scientific sampling crews }\end{array}$ & $\begin{array}{l}70 \% \text { (102 fish/hour), } \\
80 \% \text { (116 fish/hour), } \\
90 \% \text { (130 fish/hour) }\end{array}$ & $\$ 0.05$ \\
\hline
\end{tabular}




\begin{tabular}{|c|c|c|c|}
\hline $\begin{array}{l}\text { Mansfield et al. 2012, } \\
\text { Klamath River }\end{array}$ & $\begin{array}{l}\text { Increasing numbers of wild Chinook } \\
\text { salmon and steelhead trout }\end{array}$ & $\begin{array}{l}30 \% \text { increase } \\
100 \% \text { increase } \\
150 \% \text { increase }\end{array}$ & $\begin{array}{l}-\$ 19(30 \% \text { to } 100 \%) \\
\$ 11(30 \% \text { to } 150 \%)\end{array}$ \\
\hline $\begin{array}{l}\text { Mansfield et al. 2012, } \\
\text { Klamath River }\end{array}$ & Risk of extinction for suckers & $\begin{array}{l}\text { very high risk ( } 50 \% \text { to } \\
100 \% \text { ), high risk ( } 25 \% \text { to } \\
50 \% \text { ), moderate risk ( } 15 \% \\
\text { to } 25 \% \text { ) }\end{array}$ & $\begin{array}{l}\$ 41 \text { (very high to high) } \\
\$ 18 \text { (very high to } \\
\text { moderate) }\end{array}$ \\
\hline $\begin{array}{l}\text { Mansfield et al. 2012, } \\
\text { Klamath River }\end{array}$ & Risk of extinction for Coho salmon & $\begin{array}{l}\text { high risk ( } 25 \% \text { to } 50 \%) \\
\text { moderate risk ( } 15 \% \text { to } \\
25 \%) \text {, low risk ( } 10 \% \text { to } \\
15 \%)\end{array}$ & $\begin{array}{l}\text { \$39 (high to moderate) } \\
\$ 49 \text { (high to low) }\end{array}$ \\
\hline $\begin{array}{l}\text { Meyer 2012, Minnesota } \\
\text { River }\end{array}$ & $\begin{array}{l}\text { Number of years until } 50-70 \% \text { of surface } \\
\text { waters in Minnesota river basins have } \\
\text { healthy, diverse, and successfully } \\
\text { reproducing populations of aquatic } \\
\text { organisms, and suitable for swimming } \\
\text { and other water recreation }\end{array}$ & $0,1,2,3,4,5$ & $\begin{array}{l}\text { \$37 (immediate } \\
\text { cleanup) } \\
\$ 21 \text { (cleanup delayed } 5 \\
\text { years) }\end{array}$ \\
\hline $\begin{array}{l}\text { Paulrud and Laitila. 2013, } \\
\text { Em River }\end{array}$ & Accessibility, in meters from car-road & $250,750,1500$ & $-\$ 0.05$ \\
\hline $\begin{array}{l}\text { Paulrud and Laitila. 2013, } \\
\text { Em River }\end{array}$ & Bag-limit & $0,1,2$ & $\$ 45$ \\
\hline $\begin{array}{l}\text { Paulrud and Laitila. 2013, } \\
\text { Em River }\end{array}$ & $\begin{array}{l}\text { Congestion (other unknown anglers on- } \\
\text { site) }\end{array}$ & $0,10,30$ & $-\$ 6$ \\
\hline $\begin{array}{l}\text { Paulrud and Laitila. 2013, } \\
\text { Em River }\end{array}$ & Distance from home (one-way), in km & $50,300,900$ & $-\$ 0.18$ \\
\hline $\begin{array}{l}\text { Paulrud and Laitila. 2013, } \\
\text { Em River }\end{array}$ & Catch per day of salmon, $52 \mathrm{~kg}$ & $0,1,3$ & $\$ 29$ \\
\hline $\begin{array}{l}\text { Paulrud and Laitila. 2013, } \\
\text { Em River }\end{array}$ & Catch per day of salmon, $2-5 \mathrm{~kg}$ & $0,1,2$ & $\$ 44$ \\
\hline $\begin{array}{l}\text { Paulrud and Laitila. 2013, } \\
\text { Em River }\end{array}$ & Catch per day of salmon, $5-10 \mathrm{~kg}$ & $0,1,2$ & $\$ 51$ \\
\hline $\begin{array}{l}\text { Paulrud and Laitila. 2013, } \\
\text { Em River }\end{array}$ & Catch per day of salmon $>10 \mathrm{~kg}$ & $0,1,2$ & $\$ 77$ \\
\hline $\begin{array}{l}\text { Paulrud and Laitila. 2013, } \\
\text { Em River }\end{array}$ & Catch per day of sea trout $<2 \mathrm{~kg}$ & $0,1,3$ & $\$ 14$ \\
\hline $\begin{array}{l}\text { Paulrud and Laitila. 2013, } \\
\text { Em River }\end{array}$ & Catch per day of sea trout $2-5 \mathrm{~kg}$ & $0,1,2$ & $\$ 21$ \\
\hline $\begin{array}{l}\text { Paulrud and Laitila. 2013, } \\
\text { Em River }\end{array}$ & Catch per day of sea trout $>5 \mathrm{~kg}$ & $0,1,2$ & $\$ 74$ \\
\hline Stratus 2015, Elwha River & Recovery of salmon population & $\begin{array}{l}\text { No further actions, limited } \\
\text { actions, extensive actions }\end{array}$ & $\begin{array}{l}\text { \$280 (limited action) } \\
\$ 333 \text { (extensive action) }\end{array}$ \\
\hline Stratus 2015, Elwha River & $\begin{array}{l}\text { Recovery of forests and associated } \\
\text { wildlife }\end{array}$ & $\begin{array}{l}\text { No further actions, limited } \\
\text { actions, extensive actions }\end{array}$ & $\begin{array}{l}\text { \$267 (limited) } \\
\text { \$246 (extensive) }\end{array}$ \\
\hline $\begin{array}{l}\text { Weber 2015, Santa Cruz } \\
\text { River }\end{array}$ & $\begin{array}{l}\text { Miles of instream flow (vs. dry stream } \\
\text { bed) and acres of riparian } \\
\text { cottonwood/willow forest }\end{array}$ & $\begin{array}{l}9,10,13,15,17,20 \text { miles } \\
\text { of instream flow and } 45, \\
65,125,230,350,460 \\
\text { acres of forest }\end{array}$ & $\begin{array}{l}\$ 27 \text { (mid flow and } \\
\text { forest) } \\
\$ 44 \text { (full flow and } \\
\text { forest) }\end{array}$ \\
\hline $\begin{array}{l}\text { Weber 2015, Santa Cruz } \\
\text { River }\end{array}$ & Full human body contact allowed & Yes, No & $\$ 5$ \\
\hline $\begin{array}{l}\text { Weber and Stuart 2008, } \\
\text { Middle Rio Grande River }\end{array}$ & Increase in fish and wildlife populations & No increase, $10 \%$ increase & $\$ 8$ \\
\hline $\begin{array}{l}\text { Weber and Stuart 2008, } \\
\text { Middle Rio Grande River }\end{array}$ & Thinning of vegetation density & None, Moderate, Full & $\begin{array}{l}\text { \$44 (moderate) } \\
\$ 39 \text { (full) }\end{array}$ \\
\hline $\begin{array}{l}\text { Weber and Stuart 2008, } \\
\text { Middle Rio Grande River }\end{array}$ & Types of trees & $\begin{array}{l}\text { 1) Status quo (non-native } \\
\text { dominant), } \\
\text { 2) equal native and non- } \\
\text { native, } 3 \text { ) native } \\
\text { dominance }\end{array}$ & $\begin{array}{l}\text { \$38 (equal native and } \\
\text { non-native) } \\
\$ 65 \text { (native dominance) }\end{array}$ \\
\hline
\end{tabular}




\begin{tabular}{|c|c|c|c|}
\hline $\begin{array}{l}\text { Weber and Stuart 2008, } \\
\text { Middle Rio Grande River }\end{array}$ & Natural river processes & $\begin{array}{l}\text { 1) Status quo (no change } \\
\text { in management), 2) } \\
\text { controlled spring flooding } \\
\text { and floodplain } \\
\text { management to facilitate } \\
\text { river/overbank interaction }\end{array}$ & $\$ 17$ \\
\hline $\begin{array}{l}\text { Zhao et al. 2013, Pawtuxet } \\
\text { River }\end{array}$ & $\begin{array}{l}\text { Acres of river habitat accessible to } \\
\text { migratory fish (as a percentage of the } \\
\text { reference value for the watershed) }\end{array}$ & $\begin{array}{l}0 \%(0 \text { acres }), 5 \%(225 \\
\text { acres }), 10 \%(450 \text { acres }), \\
20 \%(900 \text { acres })\end{array}$ & $\$ 1.24$ \\
\hline $\begin{array}{l}\text { Zhao et al. 2013, Pawtuxet } \\
\text { River }\end{array}$ & $\begin{array}{l}\text { Probability, in percentage terms, that } \\
\text { migratory species will migrate the river in } \\
50 \text { years }\end{array}$ & $0 \%, 30 \%, 50 \%, 70 \%$ & $\$ 0.45$ \\
\hline $\begin{array}{l}\text { Zhao et al. 2013, Pawtuxet } \\
\text { River }\end{array}$ & $\begin{array}{l}\text { Accessibility of restored area for public } \\
\text { walking and fishing }\end{array}$ & Accessible, Not accessible & $\$ 34$ \\
\hline $\begin{array}{l}\text { Zhao et al. 2013, Pawtuxet } \\
\text { River }\end{array}$ & $\begin{array}{l}\text { Similarity, in percentage terms, of aquatic } \\
\text { ecological quality to the most undisturbed } \\
\text { watershed in Rhode Island }\end{array}$ & $65 \%, 70 \%, 75 \%, 80 \%$ & $\$ 0.88$ \\
\hline $\begin{array}{l}\text { Zhao et al. 2013, Pawtuxet } \\
\text { River }\end{array}$ & $\begin{array}{l}\text { Quantity of fish-eating wildlife species, in } \\
\text { percentage terms, that are common in } \\
\text { restored areas }\end{array}$ & $\begin{array}{l}55 \%(20 \text { species }) \\
60 \%(22), 70 \%(25 \\
\text { species }), 80 \%(28 \text { species })\end{array}$ & $\$ 0.65$ \\
\hline $\begin{array}{l}\text { Zhao et al. 2013, Pawtuxet } \\
\text { River }\end{array}$ & $\begin{array}{l}\text { Quantity of catchable-size fish in restored } \\
\text { areas, measured as the number of fish per } \\
\text { hour caught by scientific sampling crews }\end{array}$ & $\begin{array}{l}70 \% \text { (102 fish/hour), } \\
80 \% \text { (116 fish/hour), } \\
90 \% \text { (130 fish/hour) }\end{array}$ & -0.03 \\
\hline $\begin{array}{l}\text { Zhao et al. 2013, Pawtuxet } \\
\text { River }\end{array}$ & $\begin{array}{l}\text { Expected number of adult fish that will } \\
\text { swim upstream each year past the first } \\
\text { dam on the river (as a percentage of the } \\
\text { reference value for the watershed) }\end{array}$ & $\begin{array}{l}0 \% \text { ( } 0 \text { fish out of } 1.2 \\
\text { million possible) } \\
12 \% \text { ( } 150,000 \text { fish out of } \\
1.2 \text { million possible }) \\
20 \% \text { (245,000 fish out of } \\
1.2 \text { million possible }) \\
\%(395,000 \text { fish out of } 1.2 \\
\text { million possible })\end{array}$ & $\$ 0.70$ \\
\hline
\end{tabular}

